\title{
Covid - 19 and Stock Market Performance of Power Sector in India
}

\author{
P. Hanumantha Rao \\ Associate Professor, Department of Finance, NICMAR, Hyderabad - 500101, Telangana, India; \\ hanu.finance@gmail.com
}

\begin{abstract}
Corona virus pandemic has hit over millions of people around the world and definitely not the first epidemic the world is witnessing. In fact, the world has seen at least five such epidemics, namely, Severe Acute Respiratory Syndrome (SARS), Avian Influenza, Swine Flu, Ebola and Zikain last five years. All of these had a cascading effect on the global as well as domestic share markets. It was observed that NIFTY 50 fell as much as 15 per cent during these difficult times, but also recovered over 90 per cent return in the following one year. An investor aims to buy stocks at low and sell at high and thereby earn returns. But once an investor decides to buy a share, it will be very difficult to predict whether the price will go up or down. Stock prices are expected to perform well in long run if the fundamental of the firms are strong. On the other hand, technical analysis may help to predict the short run movement of stock prices. The study aims to assess the stock market performance of companies in power sector in India and examine the performance of the sector which in turn will affect share prices. The data is compiled from the annual reports of companies for last six years 2014-15 to 2019-20. An attempt is made to assess the stock market performance of the sector by taking five sample companies as against that of NIFTY 50 during the time of pandemic and to understand and compare the performance of the sector based on sample companies.
\end{abstract}

Keywords: Current Ratio, Net Profit Margin (NPM), Quick Ratio, Return on Capital Employed (ROCE), Stock Prices

\section{Introduction}

Theoutbreakofpandemic Covid-19hascompletely disturbed the political, social, economic, religious and financial structures of entire world community. Top most economies such as the US, China, UK, Germany, France, Italy, Japan and many others are staring at the collapse. Besides, Stock Markets around the world are going through panic and oil prices have fallen to new lows.

To control the spread of corona virus, several countries across the world resorted to lockdowns which meant confining millions of people to their homes, shutting down businesses and ceasing almost all economic activity. International Monetary Fund (IMF) anticipates the global economy to shrink by over 3 per cent in 2020. This will be the steepest slowdown since the Great Depression of the 1930s. The pandemic has already pushed the global economy into a recession, which means the economy starts shrinking and growth stops. IMF estimates the world economy to grow at -3 per cent in 2020. This is "far worse" than the 2009 global financial crises. Top most economies such as the US, Japan, the UK,

Germany, France, Italy and Spain are expected to contract this year by 5.9, 5.2, 6.5, 7, 7.2, 9.1 and 8 per cent respectively as per the estimates of IMF. Developed economies have been hit harder, and together they are expected to register a growth are of -6 per cent in 2020 whereas emerging markets and developing economies are expected to contract by -1 per cent. If China can be excluded from this pool of countries, the growth rate for 2020 is expected to come down to -2.2 per cent.

Infrastructure sector, undoubtedly, is a key driver for the growth of Indian economy in time to come. The 
sector is highly responsible for stimulating India's overall development and enjoys intense focus from Government for initiating policies that would make sure time-bound creation of world class infrastructure in the country. Infrastructure sector in India includes power, bridges, dams, roads and urban infrastructure development. In the year 2018, India was ranked $44^{\text {th }}$ out of 167 countries in World Bank's Logistics Performance Index (LPI) 2018. Power is one of the most critical components of economic infrastructure for the economic growth and welfare of nations. The existence and development of adequate infrastructure is essential for sustaining growth of the Indian economy. Power sector in India is one of the most diversified in the world. Sources of power generation varies from conventional sources such as coal, lignite, natural gas, oil, hydro and nuclear power to viable nonconventional sources such as wind, solar, and agricultural and domestic waste. Electricity demand in the country has gone up rapidly and is expected to rise further in the future. In order to meet the increasing demand for power in the country, massive addition to the installed generating capacity will be required. In May 2018, India was ranked $4^{\text {th }}$ in the Asia Pacific region out of 25 nations on an index that measures their overall power. Indian power sector is presenting undergoing a significant change that is expected to redefine the industry outlook. Sustained economic growth is the principal factor to drive demand for electricity in India. The Government of India's focus on attaining 'Power for all' has accelerated capacity addition in India. India is the third largest producer and third largest consumer of electricity in the world with installed power capacity reaching 370.49 Giga Watts (GW) as of May 2020. Electricity production touched 1,252.61 Billion Units (BU) in FY20. India was ranked as the fourth country in wind power, fifth in solar power and fifth in renewable power installed capacity in 2018. Ranking of India jumped to 22 in 2019 from 137 in 2014 on World Bank's Ease of Doing Business "Getting Electricity" rankings. India has achieved 100 per cent household electrification by March 31, 2019, as was planned under the Saubhagya scheme. Under the Saubhagya scheme of Government of India, 26.2 million households have been electrified. The Government has a budget allocation of Rs5 crore (US\$ 0.73 million) to increase capacity of Green Energy Corridor Project along with Rs 920 crore (US\$ 130 million) for wind and Rs 3,005 crore (US\$ 440 million) for solar power projects in the fiscal year 2019-20.
In the midst of positive outlook of the industry, it makes lot of sense to see how the performance of the stock prices of power sector has been in the recent past and compare it with the overall market performance. An attempt has been made in the article to understand stock performance of companies in power sector India and also examine the financial soundness of the power sector on the basis of some key financial variables. The study covers a period of six year form 2014-15 to 2019-20.

\section{Literature Review}

Balakrishnan (1984) examined the impact of dividend per share, earning per share, book value and yield on share price of general engineering and cotton textile industries in India. The study concluded that the book value per share and dividend per share turned out to be the most significant determinants of market price in both the industries. Yield also emerged as a significant determinant in cotton textile industry along with a negative sign. Srivastava (1984) conducted a crosssection study of 327 companies and observed that high dividend rates are associated with higher market prices of securities. He there fore was of the opinion that the famous Modigliani - Miller model that dividends had no impact on share prices was not applicable in the Indian context. Zahir and Khanna (1982) analyzed the determinants of stock prices in India in 101 industrial giants in the private sector for the year 1976-77 and 1977-78 with the help of multiple linear regression models. Dividend per share emerged as a significant determinant of share price, yield also emerged highly significant determinant with its negative association with market price of share. Dewenter and Malatesta (1997) presented empirical evidence on the relative profitability, leverage and labour intensity of government-owned and privately-owned firms. Crosssectional analysis of a sample of very large firms indicated that companies owned by governments are significantly less profitable than those held privately. They are also found to be more leveraged and more labour intensive. The study conducted a time series analysis of privatized firms and found little evidence that privatization enhances profitability. The study suggested that governments efficiently restructured at least some firms before selling them, but that the actual change of ownership does not give rise to further efficiency gains subsequently. 
Sathye (2001) observed that the mean efficiency score of Indian banks have scored well as compared to that of banks in the world. Cheema and Aggarwal in their study (2002) found that the commercial banks operating in India are below the average level of efficiency. Sen and Ray (2003) analyzed the key determinants of stock price in India. Their study was based upon the stocks compromising the BSE index over a period 1988-2000. The empirical study found out that dividend payout was an important factor affecting stock prices. Further, they found earning per share was found to have a very weak impact on the share prices. The study explored one of the crucial factor dividend payout ratios having impact on Indian stock price. Hartono (2004) analyzed the impact of dividend and earnings on stock prices and found significant positive impact on equity prices if positive earnings information occurs after negative dividend information. Also, a significantly negative impact occurs in equity pricing if positive dividend information is followed by negative earning information. Al-Deehani (2005) analyzed the determinants of share price for companies listed on the Kuwait stock exchange. The study showed that variables previous earnings per share, cash dividends per share, previous cash dividends per share, return on equity, and price to book value ratio, previous cash flow per share and cash flow per share are all highly correlated with the share price.

Janaki Ramudu and Durga Rao (2006) analyzed the profitability of the three major banks in India: SBI, ICICI, and HDFC for the period 2000-2005 and brought out the comparative efficiency of SBI, ICICI, and HDFC.

Agarwalla and Tuteja (2008) examined association between share price index and economic growth for India by using multi-variate Granger causality test within an error correction framework and found the causality running from economic growth proxied by industrial production to share price index and not the other way round which shows that stock markets in India are still demand driven and industry led. Gay (2008) examined the relationship among stock prices and macroeconomic variables in cases of Brazil, Russia, India and China which are emerging economies of the world using oil prices and exchange rate as explanatory variables employing Box Jenkins ARIMA model and found insignificant results which postulate inefficiency in market. Singh (2010) attempted to explore the causal relation between stock market index, that is, BSE Sensex and macroeconomic variables of Indian economy using Granger causality test.
He found that the IIP is the only variable having bilateral causal relationship with BSE Sensex. WPI had strong correlation with Sensex, but it had unilateral causality with BSE Sensex.

Somoye, et al. (2009) analyzed the factors influencing equity prices in the Nigerian stock market for the period 2005-2007. They employed simple linear regression model to examine the impact of earning per share, GDP, interest rate, dividend per share and oil price on equity price. The empirical results pointed out that the variable dividend per share, earning per share and GDP exerts a positive correlation to stock prices but are not significant determinants of share price.

Nepal and Jamasb (2011) quantitatively explored high-level links between power sector reforms and wider institutional reforms in the economy for a set of 27 diverse countries in rapid political and economic transition since 1990. Panel-data econometrics based on bias corrected dynamic fixed effect analysis (LSDVC) was performed to assess the impact of reforms on macroeconomic and power sector outcomes. The results indicated that power sector reform is indeed a more complicated process than initially perceived. The results also showed that power sector reform is greatly inter-dependent with reforms in other sectors in the economy. They were of the opinion that the success of power sector reforms on outcomes in developing countries will largely depend on the extent in which countries are able to synchronize inter-sector reforms in the economy.

Wadhwa (2009), CEO, North Delhi Power Ltd. found that the Electricity Sector of India has undergone fundamental transformation of its institutional structure after the enactment of Electricity Act 2003. One of the crucial transformations is the creation of Indian Power Market, whose objective is to unleash power forces to improve efficiencies, stimulate technical innovations and promote investments so as to bring economic benefits for the consumers and societies in the long run.

Nirmala, et al. (2011) examined the determinants of share prices in the Indian stock market. The study focuses on three sectors viz., auto, health care and public sector undertakings over the period 2000-2009. They employed panel co-integration test and fully modified least squares to examine the effect of dividend, profitability, price earnings ratio and leverage on share prices. The results showed that the dividends per share and price earnings ratio have positively influenced the share price of all three 
sectors. The results further indicated that debt equity ratio is a significant factor influencing share prices for all the three sectors and that it exerts a negative relation with share price.

Sharma (2011) analyzed the empirical relationship between equity share prices of different industry groups and explanatory variables such as book value per share, dividend per share, earning per share, price earnings ratio, dividend yield, dividend payout, size in terms of sale and net worth for the period 1993-2008. The results showed that earning per share, dividend per share and book value per share has significant impact on the equity price of different industry groups in India.

Biresh and Anandadeep Mandal (2011), in their study of the performance of the Indian banking sector during the post transition period (1997-2005) suggested that the nationalized banks are yet to exercise their cost minimizing principles compared to the other banks.

Sandhar, et al. (2013) analyzed the relationship between liquidity and profitability of selected Indian cement companies using regression analysis and observed that current ratio and liquid ratio are negatively associated with Return On Assets (ROA), Return On Investment (ROI) and cash turnover ratio is negatively associated with ROI and ROA.

Gogia and Gupta (2013) conducted a study on liquidity position and impact on profitability of Tata Steel and steel authority of India. They found that liquidity position can be improved with the help of low average collection period and average collection can be reduce by proper coordination between sale, production and finance department. They concluded that there was a positive impact of liquidity position on profitability with the help of various techniques.

Amsaveni and Gomathi (2013) conducted the fundamental analysis of BSE listed FMCG companies for a period 2006-07 to 2011-2012. They did a economic, industry and company analysis and observed that from economic analysis, GNP, Inflation, Interest rates, Exchange rate foreign exchange reserves, Agricultural Production, Government Receipts and expenditure has a positive growth rate during the study period and gross domestic product, gross domestic capital formation savings and balance of payments has negative growth rate during the study period.

Saravanan and Abarna (2014) studied liquidity position of selected automobile companies in India using
Anova and found that there is significant difference among the absolute liquid ratios of the selected automobile companies.

Based on the literature review on cross-country studies related to the power sector and stock market performances, we may argue that evidence stock performance in this sector is quite limited and will take more time to emerge. Therefore there exists a huge research gap in this area.

\section{Objectives}

The objectives of the study are as below:

- To analyze the stock market performance of companies in power sector,

- To make a comparison with the performance of benchmark index (nifty 50), and

- To analyze and compare the performance of sample companies on the basis of key areas like profitability, liquidity and efficiency.

\section{Research Methodology}

The study collected the data on NIFTY 50 on monthly basis for twelve months for the financial year 2018-19 and using it as benchmark compares with the performance of stock prices of five top power sector in India on the basis of descriptive statistics like mean, standard deviation etc. One way ANOVA is used for examining the differences among the performance of sample companies.

Sample: The present study is descriptive and analytical in nature. The sample consists of five top power generations and distribution companies on the basis of market capitalization, namely, NTPC, Power Grid Corporation, NHPC, Adani Power and Tata Power.

Key variable: The variables which have been considered in the study are

- Current Ratio (CR) and Quick Ratio (QR) which are used to measure liquidity position,

- Net Profit Margin (NPM) and Return on Capital Employed (RoCE), which are used to measure profitability position, and

- Inventory Turnover Ratio (ITR) and Assets Turnover Ratio (ATR) which are used to measure managerial efficiency.

Time Period: The period of study is from 2014-15 to 201920. 
Source of Data: The data on key variables is compiled from the annual reports of the respective banks.

\section{Hypotheses of the Study}

H01: There is no significant difference in Current Ratio between the Sample Units and within the sample units during the study period.

H02: There is no significant difference in Quick Ratio between the Sample Units and within the ample units during the study period.

H03: There is no significant difference in Net Profit Margin between the Sample Units and within the sample units during the study period.

H04: There is no significant difference in return on capital employed between the Sample Units and within the ample units during the study period.

H05: There is no significant difference in assets turnover ratio between the Sample Units and within the ample units during the study period.
H06: There is no significant difference in Inventory turnover ratio between the Sample Units and within the sample units during the study period.

Statistical Tools: The statistical tools that have been used in this study include arithmetic mean, standard deviation, Compounded Annual Growth Rate (CAGR) and one-way analysis of variance.

Limitations of the study: The following are some of the limitations of the study:

- The study takes into account only 5 top power sector companies,

- The study takes into accounts the financial data for a period of six years from 2014-15 to 2019-20, and

- Only six financial ratios are considered.

\section{Data Analysis and Interpretation}

The analysis is divided into two parts. First part deals with the performance analysis of companies in power sector over a period of twelve months from the end of October,

Table 1. Growth rate in monthly stock prices and NIFTY 50

\begin{tabular}{|l|l|l|l|l|l|l|}
\hline Month End & Nifty $\mathbf{5 0}$ & NTPC & Power Grid & NHPC & Adani Power & Tata Power \\
\hline Oct-19 & 3.51 & 4.17 & -0.35 & 5.38 & 2.80 & -4.35 \\
\hline Nov-19 & 1.50 & -4.94 & -2.55 & 1.28 & -3.71 & -3.29 \\
\hline Dec-19 & 0.93 & 2.32 & -1.58 & 0.63 & -2.83 & -1.48 \\
\hline Jan-20 & -1.70 & -5.21 & -1.79 & 2.30 & -1.21 & 2.83 \\
\hline Feb-20 & -6.36 & -5.58 & -2.86 & -15.92 & -22.52 & -19.62 \\
\hline Mar-20 & -23.25 & -20.98 & -12.34 & -3.16 & -41.33 & -29.66 \\
\hline Apr-20 & 14.68 & 12.89 & 1.85 & 4.26 & 14.05 & -3.50 \\
\hline May-20 & -2.84 & 2.95 & -2.78 & -5.77 & 15.01 & 15.30 \\
\hline Jun-20 & 7.53 & -2.10 & 10.98 & 2.04 & -1.10 & 22.71 \\
\hline Jul-20 & 7.49 & -9.19 & 1.97 & 1.50 & -1.67 & 8.58 \\
\hline
\end{tabular}


Table 1 Continued

\begin{tabular}{|l|l|l|l|l|l|l|}
\hline Aug-20 & 2.84 & 10.80 & 0.95 & 6.65 & 5.23 & 20.64 \\
\hline Sep-20 & -1.23 & -11.72 & -9.75 & -6.70 & -0.94 & -9.28 \\
\hline $\begin{array}{l}\text { Simple } \\
\text { average } \\
\text { growth rate }\end{array}$ & 0.26 & -2.22 & -1.52 & -0.63 & -3.19 & -0.09 \\
\hline $\begin{array}{l}\text { Compounded } \\
\text { average } \\
\text { growth rate } \\
\text { in stock } \\
\text { prices }\end{array}$ & $-0.17 \%$ & $-2.72 \%$ & $-1.71 \%$ & $-0.83 \%$ & $-4.73 \%$ & $-1.27 \%$ \\
\hline $\begin{array}{l}\text { S.D in } \\
\text { Growth Rate }\end{array}$ & 9.27 & 9.55 & 5.85 & 6.34 & 15.31 & 15.53 \\
\hline
\end{tabular}

2019 to the end of September, 2020 and comparing it with the performance of nifty 50 for the same period. Second part attempts to test hypothesis.

Part 1: The average value of NIFTY declined from 11877.45 points from October end, 2019 to 11247.5 point to in September end, 2020. The monthly growth rates in these values are given in (Table 1 ).

Table 1 it can be seen that Simple average Monthly Growth Rate (SMGR) is negative in case stock price of all sample companies whereas nifty 50 has registered a very small growth rate of $0.26 \%$. This is based on the data of 12 months. On the other hand, when it comes to Compounded Monthly Growth Rate (CMGR) in the stock price of the sample companies, it can be observed all have registered negative growth rates during starting from October end, 2019 to September end, 2020. During this period, nifty 50 also has registered a negative growth rate of $-0.17 \%$ which is lower than that of all sample companies. The maximum negative CMGR is seen in case of Adani power and minimum is in case power grid.

H0: There is no significant difference between the average growth rate stocks of power sector and nifty fifty.

H1: There is a significant difference between the average growth rate stocks of power sector and nifty fifty.

Table 2. One way ANOVA - SAMR in stock price

\begin{tabular}{|l|l|l|l|l|l|l|}
\hline $\begin{array}{l}\text { Source of } \\
\text { Variation }\end{array}$ & SS & df & MS & F & P-value & F crit \\
\hline $\begin{array}{l}\text { Between } \\
\text { Groups }\end{array}$ & 133.51 & 5.00 & 26.70 & 0.20 & 0.96 & 2.37 \\
\hline $\begin{array}{l}\text { Within } \\
\text { Groups }\end{array}$ & 7843.18 & 60.00 & 130.72 & & & \\
\hline Total & $\mathbf{7 9 7 6 . 6 8}$ & $\mathbf{6 5 . 0 0}$ & & & & \\
\hline
\end{tabular}


Now it can be tested whether there is significant in the growth rates of stock prices or not with the help of following ANOVA (Table 2).

Interpretation: As the calculated value (0.20) is lower than the critical value (2.37) at 5\% level of significance in Table 2, null hypothesis (H01) is accepted and hence it can be concluded that there is significant difference in the growth rates of stock prices among the sample companies as well nifty fifty. Nify 50 has registered a significant simple monthly growth rate as compared to sample companies. SAMR of Adani power is significantly lower among all other companies considered for the purpose of study.

Current ratio: It shows the relationship between the current assets and the current liabilities. It is a financial ratio that measures whether or not a company has enough resources to pay its debt over the next business cycle (usually 12 months) by comparing firm's current assets to its current liabilities. A high ratio is an indicator of "safe" liquidity, but also it can be a signal that the company may

Table 3. Current ratio

\begin{tabular}{|l|l|l|l|l|l|}
\hline & NTPC & $\begin{array}{l}\text { Power Grid } \\
\text { Corp }\end{array}$ & NHPC & Adani Power & Tata Power \\
\hline $2014-15$ & 1.22 & 0.36 & 1.88 & 0.41 & 0.59 \\
\hline $2015-16$ & 0.87 & 0.4 & 1.78 & 0.42 & 0.72 \\
\hline $2016-17$ & 0.75 & 0.38 & 1.63 & 0.23 & 0.52 \\
\hline $2017-18$ & 0.48 & 0.4 & 1.52 & 0.43 & 0.58 \\
\hline $2018-19$ & 0.79 & 0.61 & 2.07 & 0.05 & 0.55 \\
\hline $2019-20$ & 1 & 0.69 & 2.43 & 0.14 & 0.51 \\
\hline Average & 0.85 & 0.47 & 1.89 & 0.28 & 0.58 \\
\hline S.D & 0.25 & 0.14 & 0.33 & 0.16 & 0.08 \\
\hline C.V & $29.25 \%$ & $29.57 \%$ & $17.44 \%$ & $58.47 \%$ & $13.19 \%$ \\
\hline
\end{tabular}

Table 4. One way ANOVA - Current ratio

\begin{tabular}{|l|l|l|l|l|l|l|}
\hline $\begin{array}{l}\text { Source of } \\
\text { Variation }\end{array}$ & SS & df & MS & F & P-value & F crit \\
\hline $\begin{array}{l}\text { Between } \\
\text { Groups }\end{array}$ & 8.10 & 4.00 & 2.03 & 44.37 & 0.00 & 2.87 \\
\hline $\begin{array}{l}\text { Within } \\
\text { Groups }\end{array}$ & 0.91 & 20.00 & 0.05 & & & \\
\hline Total & $\mathbf{9 . 0 2}$ & $\mathbf{2 4 . 0 0}$ & & & & \\
\hline
\end{tabular}


be facing problems in getting paid its receivable or have long inventory turnover, both indicates that the company may not be efficiently using its current assets. Table 3 gives us an idea about the current ratios of the sample companies.

It can be seen that NHPC has the highest average current ratio whereas the least is found in case of Adani Power. However the highest variability is observed in case of NHPC and Tata Power has least variability in its current ratio implying that it is very much centered on its average of 0.58 . This must be improving in case of Tata Power. Now it can be tested whether there is significant difference between the current ratio of sample companies on the basis of following ANOVA (Table 4).

Interpretation: As the calculated value (44.37) is greater than the critical value (2.87) at $5 \%$ level of significance in Table 4, null hypothesis (H01) is rejected and hence it can be concluded that there is significant difference in current

Table 5. Quick ratio

\begin{tabular}{|l|l|l|l|l|l|}
\hline & NTPC & Power Grid Corp & NHPC & Adani Power & Tata Power \\
\hline $2014-15$ & 0.98 & 0.33 & 1.87 & 0.33 & 0.49 \\
\hline $2015-16$ & 0.67 & 0.36 & 1.76 & 0.38 & 0.62 \\
\hline $2016-17$ & 0.58 & 0.35 & 1.61 & 0.17 & 0.46 \\
\hline $2017-18$ & 0.7 & 0.36 & 1.77 & 0.42 & 0.55 \\
\hline $2018-19$ & 0.65 & 0.58 & 2.05 & 0.05 & 0.51 \\
\hline $2019-20$ & 0.81 & 0.65 & 2.43 & 0.14 & 0.45 \\
\hline Average & 0.73 & 0.44 & 1.92 & 0.25 & 0.51 \\
\hline S.D & 0.14 & 0.14 & 0.29 & 0.15 & 0.06 \\
\hline C.V & $19.55 \%$ & $31.72 \%$ & $15.20 \%$ & $59.91 \%$ & $12.36 \%$ \\
\hline
\end{tabular}

Table 6. One way ANOVA - Quick ratio

\begin{tabular}{|l|l|l|l|l|l|l|}
\hline $\begin{array}{l}\text { Source of } \\
\text { Variation }\end{array}$ & SS & df & MS & F & P-value & F crit \\
\hline $\begin{array}{l}\text { Between } \\
\text { Groups }\end{array}$ & 8.94 & 4.00 & 2.24 & 68.34 & 0.00 & 2.87 \\
\hline $\begin{array}{l}\text { Within } \\
\text { Groups }\end{array}$ & 0.65 & 20.00 & 0.03 & & & \\
\hline Total & $\mathbf{9 . 6 0}$ & $\mathbf{2 4 . 0 0}$ & & & & \\
\hline
\end{tabular}


ratio between the sample companies. Hence, it can be noted that NHPC has best liquidity position among the sample companies. Adani Power has to improve its liquidity position as it has least average current ratio.

Quick Ratio: The quick ratio or acid test ratio is a liquidity ratio which is used to measures the ability of a company to pay its current liabilities when they become due with only quick assets. Quick assets are current assets that can be converted to cash within 90 days or in the shortterm. Cash, cash equivalents, short-term investments or marketable securities, and current accounts receivable are considered quick assets. It is measured as quick assets divided by current liabilities. Table 5 gives us an idea about the quick ratios of the ample companies.

Table 5 it can be seen that the average QR is best for NHPC followed by NTPC. It is Adani Power which has least QR. Highest variability was observed in case of NHPC whereas least variability was noticed in case Tata Power. The QR reflects the same situation as was reflected by CR. But whether these differences are significant or not, it can be seen from the following ANOVA (Table 6).
Interpretation: As the calculated value (68.34) is greater than the critical value (2.87) at $5 \%$ level of significance in Table 6, null hypothesis (H02) is rejected and hence it can be concluded that there is significant difference in the quick ratio between the sample companies. Hence, it can be said that NHPC has best liquidity position compared to other sample companies based on quick ratio as well as current ratio.

Net Profit Margin: Net profit margin gives an idea about how much a company earns (after interest and taxes) on each rupee of sales. In other worlds, the higher a company's operating profit margin is the better off the company is. If a company's margin is increasing, it is earning more per rupee of sales. Table 7 gives us an idea about the net profit margin of sample companies under study.

Table 7, it can be seen that the average net profit margin of NHPC is highest whereas least net profit margin is Adani Power at -33.10 with maximum variability. Now, whether these differences can be treated significant or not, it can be observed by referring the following (Table 8).

Table 7. Net profit margin

\begin{tabular}{|l|l|l|l|l|l|}
\hline & NTPC & Power Grid Corp & NHPC & Adani Power & Tata Power \\
\hline $2014-15$ & 14.04 & 28.98 & 31.23 & -0.64 & 11.64 \\
\hline $2015-16$ & 15.2 & 28.97 & 32.82 & 0.74 & 15.58 \\
\hline $2016-17$ & 11.99 & 29.24 & 38.44 & -55.7 & 5.74 \\
\hline $2017-18$ & 12.39 & 27.69 & 39.78 & -0.28 & -41.8 \\
\hline $2018-19$ & 13.01 & 29.12 & 32.23 & -9.36 & 21.42 \\
\hline $2019-20$ & 10.35 & 29.87 & 34.42 & -133.34 & 1.91 \\
\hline Average & $\mathbf{1 2 . 8 3}$ & $\mathbf{2 8 . 9 8}$ & $\mathbf{3 4 . 8 2}$ & $\mathbf{- 3 3 . 1 0}$ & $\mathbf{2 . 4 2}$ \\
\hline S.D & $\mathbf{1 . 6 8}$ & $\mathbf{0 . 7 1}$ & $\mathbf{3 . 5 1}$ & $\mathbf{5 3 . 6 6}$ & 22.74 \\
\hline C.V & $13.12 \%$ & $2.46 \%$ & $10.07 \%$ & $-162.14 \%$ & $941.68 \%$ \\
\hline
\end{tabular}


Table 8. One way ANOVA - net profit margin

\begin{tabular}{|c|c|c|c|c|c|c|}
\hline $\begin{array}{c}\text { Source of } \\
\text { Variation }\end{array}$ & SS & df & MS & F & P-value & F crit \\
\hline $\begin{array}{c}\text { Between } \\
\text { Groups }\end{array}$ & 17692.79 & 4.00 & 4423.20 & 5.64 & 0.00 & 2.87 \\
\hline $\begin{array}{c}\text { Within } \\
\text { Groups }\end{array}$ & 15678.94 & 20.00 & 783.95 & & & \\
\hline Total & $\mathbf{3 3 3 7 1 . 7 3}$ & $\mathbf{2 4 . 0 0}$ & & & & \\
\hline
\end{tabular}

Interpretation: As the calculated value (5.64) is greater than the critical value (2.87) at $5 \%$ level of significance in (Table 8), null hypothesis (H03) is rejected and hence it can be concluded that there is significant difference in the operating margin between the sample companies. Hence, it is observed that NHPC has best net profit margin, but Adani Power must look into this.
Return on Capital Employed (ROCE): ROCE is a financial ratio which measures a company's profitability and the efficiency with which its capital is employed. A higher ROCE is an indication of more efficient use of capital. ROCE should always be higher than the cost of capital of the company; otherwise it indicates that the company is not employing its capital effectively and is not

Table 9. ROCE

\begin{tabular}{|l|l|l|l|l|l|}
\hline & NTPC & $\begin{array}{l}\text { Power Grid } \\
\text { Corp }\end{array}$ & NHPC & Adani Power & Tata Power \\
\hline $2014-15$ & 6.17 & 3.64 & 4.29 & -0.27 & 3.7 \\
\hline $2015-16$ & 5.94 & 3.93 & 4.91 & 0.35 & 11.74 \\
\hline $2016-17$ & 8.3 & 9.57 & 8.13 & -24 & 9.15 \\
\hline $2017-18$ & 7.57 & 9.86 & 7.79 & -0.2 & 12.25 \\
\hline $2018-19$ & 7.48 & 16.84 & 7.09 & 9.36 & 11.09 \\
\hline $2019-20$ & 7.88 & 16.77 & 6.91 & 4.38 & 10.82 \\
\hline Average & 7.22 & $\mathbf{1 0 . 1 0}$ & 6.52 & -1.73 & 9.79 \\
\hline S.D & 0.95 & 5.83 & 1.57 & 11.53 & 3.17 \\
\hline C.V & $13.18 \%$ & $57.73 \%$ & $24.00 \%$ & $-666.66 \%$ & $32.33 \%$ \\
\hline
\end{tabular}


generating shareholder any value. Table 9 gives an idea about the ROCE of the sample companies in power sector in India.

Table 9, it is observed that average return on capital employed is highest for Power Grid followed by Tata Power and least is found in case of Adani Power. The maximum variability was also noticed in case of Adani
Power whereas it was most stable for NTPC. Now, whether this difference can be taken significantly or not can be observed by looking at the ANOVA in (Table 10).

Interpretation: As the calculated value (3.67) is greater than the critical value (2.87) at $5 \%$ level of significance in the above Table, null hypothesis (H04) is rejected and hence it can be concluded that there is significant

Table 10. One way ANOVA - ROCE

\begin{tabular}{|c|c|c|c|c|c|c|}
\hline $\begin{array}{c}\text { Source of } \\
\text { Variation }\end{array}$ & SS & df & MS & F & P-value & F crit \\
\hline $\begin{array}{c}\text { Between } \\
\text { Groups }\end{array}$ & 584.82 & 4.00 & 146.20 & 3.67 & 0.02 & 2.87 \\
\hline $\begin{array}{c}\text { Within } \\
\text { Groups }\end{array}$ & 797.52 & 20.00 & 39.88 & & & \\
\hline Total & $\mathbf{1 3 8 2 . 3 4}$ & $\mathbf{2 4 . 0 0}$ & & & & \\
\hline
\end{tabular}

Table 11. ATR

\begin{tabular}{|l|l|l|l|l|l|}
\hline & NTPC & $\begin{array}{l}\text { Power Grid } \\
\text { Corp }\end{array}$ & NHPC & Adani Power & Tata Power \\
\hline $2014-15$ & 37.16 & 10.85 & 12.26 & 28.16 & 25.85 \\
\hline $2015-16$ & 32.92 & 11.65 & 13.47 & 28.27 & 25.12 \\
\hline $2016-17$ & 33.08 & 13.2 & 13.9 & 26.02 & 16.95 \\
\hline $2017-18$ & 32.07 & 13.97 & 12.96 & 41.86 & 20.64 \\
\hline $2018-19$ & 31.04 & 13.84 & 13.69 & 8.31 & 21.64 \\
\hline 201920 & 29.81 & 14.15 & 13.51 & 4.46 & 20.53 \\
\hline Average & $\mathbf{3 2 . 6 8}$ & $\mathbf{1 2 . 9 4}$ & $\mathbf{1 3 . 3 0}$ & $\mathbf{2 2 . 8 5}$ & $\mathbf{2 1 . 7 9}$ \\
\hline S.D & $\mathbf{2 . 5 1}$ & $\mathbf{1 . 3 7}$ & $\mathbf{0 . 6 0}$ & $\mathbf{1 3 . 9 9}$ & $\mathbf{3 . 2 8}$ \\
\hline C.V & $\mathbf{7 . 6 9} \%$ & $\mathbf{1 0 . 6 1 \%}$ & $\mathbf{4 . 4 9 \%}$ & $\mathbf{6 1 . 2 3} \%$ & $15.07 \%$ \\
\hline
\end{tabular}


difference in the Return on capital employed between the sample companies. Hence, Power Grid Corp has been able to generate highest return on capital employed with more stability whereas Adani Power must be a bit worried for their return on capital employed.

Assets Turnover Ratio: The asset turnover ratio simply compares the turnover with the assets which the business has used to generate that turnover. It measures how much turnover a firm is able to generate for each rupee invested in the form of assets. It is measured as sales divided by average total assets (Table 11).

Table 11, it can be observed that it is NTPC which has best assets turnover ratio, followed by Adani Power and Tata Power. That means these companies are generating highest turnover using their assets. The Power Grid Corp has got least activity ratio which indicates that it generates

Table 12. One way ANOVA - ATR

\begin{tabular}{|c|c|c|c|c|c|c|}
\hline $\begin{array}{c}\text { Source of } \\
\text { Variation }\end{array}$ & SS & df & MS & F & P-value & F crit \\
\hline $\begin{array}{c}\text { Between } \\
\text { Groups }\end{array}$ & 1144.17 & 4.00 & 286.04 & 5.77 & 0.00 & 2.87 \\
\hline $\begin{array}{c}\text { Within } \\
\text { Groups }\end{array}$ & 991.03 & 20.00 & 49.55 & & & \\
\hline Total & $\mathbf{2 1 3 5 . 2 0}$ & $\mathbf{2 4 . 0 0}$ & & & & \\
\hline
\end{tabular}

Table 13. ITR

\begin{tabular}{|l|l|l|l|l|l|}
\hline & NTPC & $\begin{array}{l}\text { Power Grid } \\
\text { Corp }\end{array}$ & NHPC & Adani Power & Tata Power \\
\hline $2014-15$ & 9.83 & 23.93 & 82.22 & 10.82 & 12.97 \\
\hline $2015-16$ & 10.11 & 25.26 & 86.92 & 15.5 & 12.62 \\
\hline $2016-17$ & 12.03 & 28.35 & 79.34 & 10.02 & 10.32 \\
\hline $2017-18$ & 13.78 & 28.65 & 72.4 & 110.45 & 15.89 \\
\hline $2018-19$ & 11.31 & 27.82 & 69.67 & 587.82 & 14.25 \\
\hline $2019-20$ & 9.1 & 25.84 & 73.88 & 247.62 & 12.17 \\
\hline Average & $\mathbf{1 1 . 0 3}$ & $\mathbf{2 6 . 6 4}$ & 77.41 & $\mathbf{1 6 3 . 7 1}$ & $\mathbf{1 3 . 0 4}$ \\
\hline S.D & $\mathbf{1 . 7 1}$ & $\mathbf{1 . 9 1}$ & 6.55 & 227.47 & 1.89 \\
\hline C.V & $15.52 \%$ & $7.17 \%$ & $8.47 \%$ & $138.95 \%$ & $14.52 \%$ \\
\hline
\end{tabular}


Table 14. One way ANOVA - ITR

\begin{tabular}{|c|c|c|c|c|c|c|}
\hline $\begin{array}{c}\text { Source of } \\
\text { Variation }\end{array}$ & SS & df & MS & F & P-value & F crit \\
\hline $\begin{array}{c}\text { Between } \\
\text { Groups }\end{array}$ & 119297.04 & 4.00 & 29824.26 & 2.58 & 0.07 & 2.87 \\
\hline $\begin{array}{c}\text { Within } \\
\text { Groups }\end{array}$ & 230887.61 & 20.00 & 11544.38 & & & \\
\hline Total & $\mathbf{3 5 0 1 8 4 . 6 6}$ & $\mathbf{2 4 . 0 0}$ & & & & \\
\hline
\end{tabular}

only Rs. 12.94 for every 1 rupee invested in the form of assets on an average. To see whether there is significance difference in the assets turnover ratio of the firm, the following ANOVA (Table 12) is referred.

Interpretation: As the calculated value (5.77) is greater than the critical value (2.87) at $5 \%$ level of significance in (Table 12), null hypothesis (H08) is rejected and hence it can be concluded that there is significant difference in the asset turnover ratio between the sample companies. Hence, it can be said that companies likes NTPC, Adani Power and Tata Power are making best use of their assets by generating maximum turnover compared to other two sample companies.

Inventory Turnover Ratio: The inventory turnover ratio is an efficiency ratio which shows how effectively inventory is managed by comparing cost of goods sold with average inventory for a given period. This measure how many times, on an average, inventory is "turned" or sold during a year. Higher the inventory turnover better is the efficiency of the firm (Table 13).

Table 13, it can be observed that it is Adani power which has best average inventory turnover ratio followed by NHPC and Power Grid. NTPC has got least inventory turnover ratio. Highest variability is noticed in case of Adani Power. To see whether there is significance difference in the assets turnover ratio of the firm, the following ANOVA (Table 14) is referred.

Interpretation: As the calculated value (2.58) is lower than the critical value (2.87) at $5 \%$ level of significance in (Table 14), null hypothesis (H08) is accepted and hence it can be concluded that there is no significant difference in the inventory turnover ratio between the sample companies.

\section{Finding}

From the above analysis, following important findings may be summarized:

- Growth rate in the stock prices on monthly basis was found to be significantly different among the sample companies. The CMGR in case of Adani power was found to be least and in case of power grid, it was better among the sample companies,

- Sample companies differed significantly based on current ratio. NHPC has the best liquidity position based on current ratio among the sample companies whereas the Adani Power must work on to improve its current ratio,

- Sample companies also differed significantly based on quick ratio. It is NHPC only which scores over other companies on this parameter. Adani Power was found to have least quick ratio,

- So, both current ratio and quick ratio suggest that NHPC has the strongest liquidity position whereas Adani Power's liquidity position needs improvement,

- Net profit margin of the sample companies differed significantly. It was highest for NHPC and Lowest for Adani Power which also had lot of fluctuations in their NPM over the period of study,

- Return on capital employed also differed significantly among the sample companies. The highest average ROCE was observed in case of NTPC which was 
able to generate a return of $7.02 \%$ return on capital employed on an average, followed by NTPC and NHPC. Adani Power could generate negative average return on capital employed at $-4.37 \%$. Further, this return was subject to lot of variability over the period of study,

- Assets turnover ratios also differed significantly among the sample companies. The highest average assets turnover was observed in case of NTPC at 35.07 which implied that company is able to generate revenue of Rs 35.07 for every one rupee invested in assets. Adani power was second best among the sample companies,

- Inventory turnover ratio was also found to differ significantly among the sample companies. NHPC has best inventory turnover ratio followed by Adani Power, and

- Of the five sample companies, NHPC and NTPC found to have strong fundamentals whereas Adani Power needs to improve its liquidity and profitability despite the fact that the stock prices of the companies have outperformed all others including nifty fifty over the period of study.

\section{References}

1. Agarwalla, R.K., \& Tuteja, S.K. (2008). Share prices and macroeconomic variables in India: An approach to investigate the relationship between stock markets and economic growth. Journal of Management Research, 8(3), 136-146.

2. Al-Deehani, T. M. (2005). Determinants of dividend policy: The case of Kuwait. The Arab Journal of Economic and Administrative Sciences, 19(2), 59-76. https://doi. org/10.1108/10264116200300006.

3. Amsaveni, R., \& Gomathi, S. (2013). Fundamental analysis of selected FMCG companies in India. Asia Pacific Finance and Accounting Review, 1(3), 37-55.

4. Balakrishnan (1984). Determinants of equity prices in India. Management Accountant, 19(12), 728-730.

5. Biresh, K. S., \& Anandadeep Mandal (2011). Examining the performance of banks in India: Post transition period. IUP Journal of Bank Management. X(2), 7-31.

6. Cheema, C. S., \& Aggarwal Monika (2002). Productivity in commercial banks: A DEA approach. The Business Review, 8(1\&2), 15-17.
7. Dewenter, Kathryn \& Paul H. Malatesta (1997). Public offerings of state-owned and privately owned enterprises: An International comparison. J. Fin. 52, 1659-79. https:// doi.org/10.1111/j.1540-6261.1997.tb01125.x.

8. Gay, D. (2008). Effects of Macroeconomic Variables on Stock Market Returns for Emerging Economies: Brazil, Russia, India and China. International Business and Economic Research Journal, 7(3), 1-8.

9. Gogia, N., \& Gupta, D.K. (2013). Comparative study on liquidity position of Indian public sector steel units and private sector steel authority of India Ltd. VSRD International Journal of Business and Management Research, 3(7), 261-268.

10. Hartono, J. (2004). The Recency Effect of accounting information. GadjahMada International Journal of Business, 6(1): 85-116. https://doi.org/10.22146/ gamaijb.5536, https://doi.org/10.22146/gamaijb.5535.

11. Janaki Ramudu, P. S., \& Durga Rao (2006). A fundamental analysis of Indian banking industry. IPU Journal of Bank Management, V(4), 68-79.

12. Nepal, R., \& Jamasb, T. (2011). Reforming the Power Sector in Transition: Do Institutions Matter? Cambridge Working Papers in Economics, University of Cambridg; p. 1124.

13. Nirmala, P. S., Sanju, P. S., \& Ramachandran, M. (2011). Determinants of share prices in India. Journal of Emerging Trends in Economics and Management Sciences, 2(2), 124-130.

14. Sandhar, Kaur, S., Janglani, \& Silky. (2013). A study on liquidity and profitability of selected Indian cement companies: A regression modelling approach. International Journal of Economics, Commerce and Management, 1(1), 1-24.

15. Saravanan, S. S., \& Abarna, J. (2014). A study on liquidity analysis of selected automobile companies in India. Indian Journal of Applied Research, 4(2), 6-8. https:// doi.org/10.15373/2249555X/FEB2014/31.

16. Sathye, Milind (2001). Efficiency of banks in a developing economy: The case of India, School of Accounting, Banking and Finance, University of Canberra, 148, 662671. https://doi.org/10.1016/S0377-2217(02)00471-X.

17. Sen, S., \& Ray, R. (2003). Key determinants of stock prices in India. The ICFAI Journal of Applied Finance, 9(7), 35-40.

18. Sharma, S. (2011). Determinants of equity share prices in India. Journal of Arts, Science and Commerce, 2(4), 51-60. 
19. Singh, D. (2010). Causal relationship between macroeconomic variables and stock market? A case study of India. Pakistan Journal of Social Sciences, 30(2), 263-274

20. Somoye, R. O. C., Akintoye, I. R., \& Oseni, J. E. (2009). Determinants of equity prices in the stock markets. International Research Journal of Finance and Economics, 30, 177-189.

21. Srivastava, R. M. (1984). Testing Modigliani - Millers dividend valuation model in Indian context - A case study of 327 joint stock companies. Management Accountant, 19(11), 641-642.

22. Wadhwa, S. (2009). Electricity Market Development: Draft CERC Regulations. Infraline Energy Thought Leadership Series, Round Table Discussions Delhi.

23. Zahir, M. A., \& Khanna, Y. (1982). Determinants of stock prices in India. The Chartered Accountant, 30(8), 521-523. 